\title{
Review
}

\section{Steroid signal transduction activated at the cell membrane: from plants to animals ${ }^{\star}$}

Ewa Marcinkowska ${ }^{1 凶}$ and Antoni Więdłocha ${ }^{2}$

${ }^{1}$ Department of Reproductive Immunology, Institute of Immunology and Experimental Therapy, Polish Academy of Sciences, Wroctaw, Poland; and ${ }^{2}$ Department of Biochemistry, Institute for Cancer Research, The Norwegian Radium Hospital, N-0310 Oslo, Norway

Received: 25 June, 2002; revised: 12 August, 2002; accepted: 25 August, 2002

Key words: steroid hormones, nuclear receptors, membrane receptors, transcription factors, signal transduction pathways, translocation

\begin{abstract}
Steroid hormones in plants and in animals are very important for physiological and developmental regulation. In animals steroid hormones are recognized by nuclear receptors, which transcriptionally regulate specific target genes following binding of the ligand. In addition, numerous rapid effects generated by steroids appear to be mediated by a mechanism not depending on the activation of nuclear receptors. Although the existence of separate membrane receptors was postulated many years ago and hundreds of reports supporting this hypothesis have been published, no animal membrane steroid receptor has been cloned to date. Meanwhile, a plant steroid receptor from Arabidopsis thaliana has been identified and cloned. It is a transmembrane protein which specifically recognizes plant steroids (brassinosteroids) at the cell surface and has a serine/threonine protein kinase activity. It seems that plants have no intracellular steroid receptors, since there are no genes homologous to the family of animal nuclear steroid receptors in the genome of $A$. thaliana.

Since the reason of the rapid responses to steroid hormones in animal cells still remains obscure we show in this article two possible explanations of this phenomenon. Using 1,25-dihydroxyvitamin $D_{3}$ as an example of animal steroid hormone, we review results of our and of other groups concordant with the hypothesis of membrane ste-
\end{abstract}

\footnotetext{
${ }^{\star}$ Presented at the VIII Polish Conference on Cell Biology, September, 23-25, 2002, Wrocław, Poland.

${ }^{\bowtie}$ Corresponding author: Ewa Marcinkowska, Department of Reproductive Immunology, Institute of Immunology and Experimental Therapy, Polish Academy of Sciences, R. Weigla 12, 53-114 Wrocław, Poland; e-mail: marcinko@iitd.pan.wroc.pl webpage http://www.ii.uni.wroc.pl/ ema/
}

Abbreviations: BR, brassinosteroids; BRI-1, brassinosteroid-insensitive 1; ER, estrogen receptor; FGF-1, fibroblast growth factor-1; PI 3-K, phosphatidylinositol 3-kinase; PKA, protein kinase A; PKC, protein kinase C; PLC, phospholipase C; RE, response element; nVDR, nuclear vitamin D receptor. 
roid receptors. We also review the results of experiments performed with ovarian hormones, that led their authors to the hypothesis explaining rapid steroid actions without distinct membrane steroid receptors. Finally, examples of polypeptide growth factor that similarly to steroids exhibit a dual mode of action, activating not only cell surface receptors, but also intracellular targets, are discussed.

\section{STEROID HORMONES IN ANIMALS AND PLANTS}

All plant and animal steroid hormones are cholesterol derivatives, synthesized by the organisms. Physiologic effects of steroid hormones are necessary for regulation of growth, development and homeostasis. The majority of steroid hormones retain the four ring core of cholesterol (Fig. 1) with one exception of vitamin $\mathrm{D}$, where B-ring is broken. In vertebrates steroids are a very large group of hormones which includes sex hormones, glucocorticoids, corticosteroids, metabolites of vitamin $\mathrm{D}_{3}$ and neurosteroids. In insects ecdysteroids are absolutely necessary for development, growth and molting (Bollenbacher et al., 1975). Also in plants steroid hormones (brassinosteroids) are essential for growth

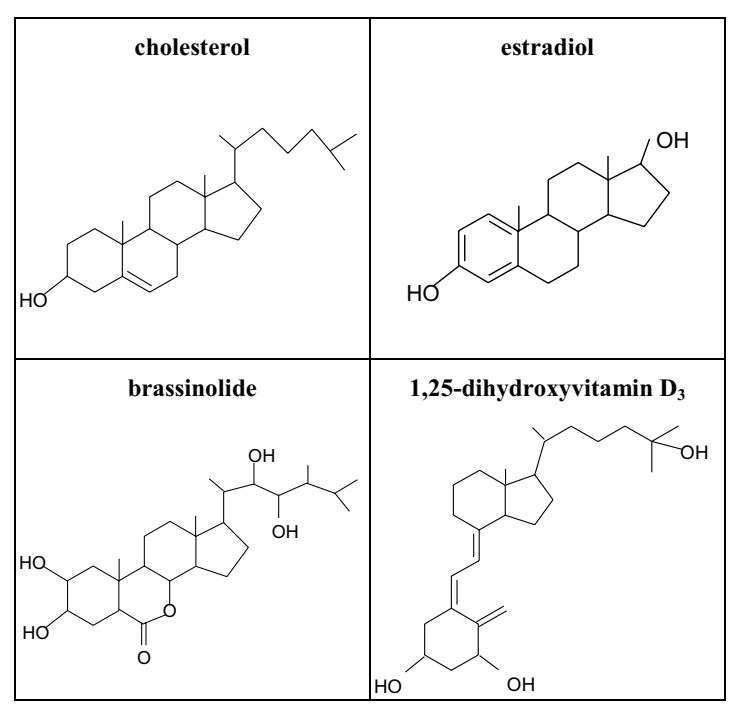

Figure 1. Chemical structures of cholesterol and some steroid hormones.

Brassinolide (the most active brassinosteroid from plants), estradiol (an animal ovarian hormone) and 1,25-dihydroxyvitamin $\mathrm{D}_{3}$ (the hormonally active form of vitamin D). and differentiation. Mutant plants deficient in brassinosteroid synthesis exhibit dwarfism, delayed senscence, reduced fertility and light-independent development (Wang \& Chory, 2000).

\section{NUCLEAR STEROID RECEPTORS IN ANIMALS}

The nuclear steroid hormone receptor superfamily has been known for over two decades (Evans, 1988). This superfamily includes also receptors for retinoids, thyroid hormones and a subfamily of so called orphan receptors with still unidentified ligands. All these receptors act as ligand inducible transcription factors. They share many structural similarities, all have a short DNA-binding domain with two characteristic zinc fingers. After binding of the ligand to the hydrophobic ligand binding domain, the activated receptor recognizes appropriate response element (RE) in the promoter region of the target gene. For their transcriptional activity the majority of nuclear receptors need to dimerize forming either homodimers (e.g. estrogen receptor) or heterodimers (e.g. vitamin D receptor/retinoic acid receptor). Although studies on the molecular mechanism of transcriptional regulation by nuclear receptors are progressing very rapidly, the understanding of the process is still far from satisfactory (Di Croce et al., 1999). Greatly simplified, the whole process could be described as follows. Binding of the activated nuclear receptor to the appropriate $\mathrm{RE}$ induces a bend in the promoter DNA. Changes in conformation of the nuclear receptor allow coactivator proteins to interact with the complex. Since some components of the coactivator complex exhibit histone acetyltransferase activity, formation of this com- 
plex results in acetylation of histones and remodelling of the DNA structure. This in turn allows the transcriptional machinery to reach the target gene. In some cases binding of the liganded receptor to the response element leads to decreased transcription of the target gene in a not yet fully understood way. Activation of a nuclear receptor by its ligand induces cellular effects after a relatively long time, ranging from dozens of minutes to several hours.

\section{RAPID RESPONSES TO STEROID HORMONES}

Most steroid hormones induce in the target cells responses too rapid to involve transcriptional regulation. The classic example was published by Hans Selye in 1941 (Selye, 1941) reporting immediate anesthesia after administration of progesterone at pharmacologic concentrations. Hundreds of publications documenting rapid effects of steroids have been published since then. These effects resemble cellular responses induced by growth factors and protein hormones that are recognized at the cell membrane by specific transmembrane protein receptors. Different steroid hormones induce in their target cells rapid raises of intracellular calcium levels (Machelon et al., 1998). They are able to activate protein kinases C and A (Kelly et al., 1999), G proteins (Rosner et al., 1999), MAPK cascade (Marcinkowska et al., 1997) or phospholipase $\mathrm{A}_{2}$ (Schwartz et al., 1988). Since these studies have been performed on different experimental models, and cellular responses to various steroid hormones are also different it is very difficult to give a summary of membrane-mediated responses generated by steroid hormones. This is why only a selected group of papers will be discussed here in order to present two possible explanations for the rapid cellular responses to steroid hormones.

\section{NON-TRANSCRIPTIONAL CONTRI- BUTION TO ACTIVATION OF PROLIFERATION BY OVARIAN HORMONES}

Ovarian hormones are potent stimulators of mitogenesis for breast cancer cells. Experimental model of hormone-induced mitogenesis of breast cancer cells served a group of researchers from Naples to show the biological meaning of rapid cellular responses generated by these hormones. In a series of exhaustive papers the authors showed that estradiol induces proliferation through activation of the Src/Ras/Erks signalling pathway in MCF-7 and T47D cells (Migliaccio et al., 1993; 1996; Castoria et al., 1999) similarly to progestins that activate this same pathway in T47D cells (Migliaccio et al., 1998). Rapid activation of this pathway was necessary for S-phase entry of the cells and could be blocked by antiestrogens as well as by anti-progestins. The authors have proved that the expression of both estrogen nuclear receptors (ER) and progesterone nuclear receptors (PR) in breast cancer cells is necessary for the activation of Src/Ras/Erks. They showed that liganded ER interacts with c-Src, while PR interacts with ER and these interactions create a cross-talk between the transcriptional and non-transcriptional activities of ovarian hormones. Recently the same authors found that also the phosphatidylinositol (PI) 3-kinase/Akt signal transduction pathway mediates the estradiol-induced S-phase entry and induction of cyclin D1 in MCF-7 cells (Castoria et al., 2001). Hormone-induced stimulation of PI 3-kinase and Akt is Src dependent. Pull-down experiments revealed that estradiol triggers association of ER with Src and PI 3-kinase, which does not occur in the absence of the hormone.

Summarizing, the authors of the cited papers do not postulate the existence of separate membrane receptors responsible for the rapid cellular responses to ovarian hormones. On the basis of the experimental data they hy- 
pothesize that rapid estradiol- or progestin-induced activation of cell signalling results from different scaffolding of proteins belonging to the signal transduction pathways. This hypothesis does not violate the widely accepted paradigm that nuclear receptors are the only steroid receptors in animal cells. It should be noticed, however, that specific binding sites for estrogens in the cell membrane of endometrial cells were described many years ago (Pietras \& Szego, 1977) and that some reports suggest that this membrane estrogen binding protein is derived from the same transcript as nuclear ER (Razandi et al., 1999). It has been shown recently that ER associate with calveolin, an important structural component of calveolae (Razandi et al., 2002). Calveolae are cell membrane microstructures, where various intracellular signals are initiated.

\section{METABOLITES AND ANALOGS OF VITAMIN D AS TOOLS FOR STUDYING THE NON-TRANSCRIP- TIONAL MECHANISM OF ACTION OF STEROID HORMONES}

Vitamin D differs from other steroid hormones in its chemical structure (see Fig. 1). It is a derivative of cholesterol as all other steroid hormones, but its B ring of the cholesterol core is broken. This feature makes the molecule extremely flexible. The physiological functions of vitamin D are very broad (Jones et al., 1998). Only its hydroxylated metabolites are active in the organism. The most active is 1,25-dihydroxyvitamin $\mathrm{D}_{3}$, but also 24,25-dihydroxyvitamin $\mathrm{D}_{3}$ is necessary for bone formation. Initially, emphasis was placed only on the function of vitamin $\mathrm{D}$ metabolites in skeleton development (so called "calcemic function"). However, further studies revealed its role in differentiation of many cell types. This twofold activity of vitamin D metabolites raised hope that chemical modifications of the molecule would enable uncou- pling of the calcemic and differentiation-inducing activities of the hormone. In fact there are hundreds of vitamin $\mathrm{D}$ analogs described in the literature at present, and many of them fulfill these requirements. Some of them are deprived of their calcemic function, but retain the ability to induce cell differentiation (Bouillon et al., 1995). Although the nuclear vitamin D receptor (nVDR) was cloned many years ago, its crystal structure had not been solved until recently (Rochel et al., 2000). It was believed that analogs of vitamin $\mathrm{D}$ that are particularly active in the induction of cell differentiation cause conformational changes in the structure of $\mathrm{nVDR}$ responsible for their higher biological activity. Surprisingly, the crystal structures of $\mathrm{nVDR}$ complexed to 20-epi analogs (superagonists) of vitamin D revealed that the lipid-binding domain conformation is the same as for 1,25-dihydroxyvitamin $\mathrm{D}_{3}$ (Tocchini-Valentini et al., 2001). So there must be another mechanism through which this higher differentiation-inducing activity could be achieved.

The phenomenon that the affinity of a particular vitamin $\mathrm{D}$ analog for $\mathrm{nVDR}$ is not directly proportional to its differentiation-inducing activity had been observed before the solution of the nVDR crystal structure was obtained. For example (see Table 1): an analog of vitamin $\mathrm{D}_{3}$ with extended side chain (analog 1), synthesized in the Pharmaceutical Research Institute in Warsaw (Poland), which binds nVDR with a 10 times higher affinity than 1,25-dihydroxyvitamin $\mathrm{D}_{3}$, induces cell differentiation similarly to the parent compound (Chodyński et al., 1997; Marcinkowska et al., 1998). Another analog with unsaturated side-chain (analog 2), also synthesized in the Pharmaceutical Research Institute in Warsaw (Chodyński et al., 2002), is able to induce HL-60 cell differentiation much stronger than 1,25-dihydroxyvitamin $\mathrm{D}_{3}$ (Marcinkowska, 1998). In the same HL-60 cells 1,25-dihydroxyvitamin $\mathrm{D}_{3}$ induces rapid activation of Erk kinases (Marcinkowska et al., 1997). This response is too fast to be regulated trans- 
Table 1. Differentiation of HL-60 cells induced by 1,25-dihydroxyvitamin $D_{3}$ and by its two analogs.

The table uses data taken from Marcinkowska et al. (1998) (analog 1) and Marcinkowska (1998) analog 2). HL-60 cells after 96-h treatment with the compounds were tested for their ability to:

- phagocyte Saccharomyces cervisiae. Mean percentage of phagocyting cells is presented.

- reduce yellow $\mathrm{NBT}^{1}$ to dark blue formazan. Mean percent of positive cells is presented.

- express the CD11b and CD14 cell surface markers. Table shows mean channel of fluorescence (MC) of cells expressing either CD11b or CD14 measured in flow cytometry.

Means \pm S.D. were calculated from at least three experiments.

\begin{tabular}{llllcc}
\hline Compound & $\begin{array}{l}\text { Conc. } \\
{[\mathrm{nM}]}\end{array}$ & $\begin{array}{l}\text { Phagocytosis } \\
{[\%]}\end{array}$ & $\begin{array}{l}\text { NBT reduction } \\
{[\%]}\end{array}$ & $\begin{array}{l}\text { CD11b } \\
{[\mathrm{MC}]}\end{array}$ & $\begin{array}{l}\text { CD14 } \\
{[\mathrm{MC}]}\end{array}$ \\
\hline Control & none & $0.7 \pm 0.8$ & $2.6 \pm 2.8$ & $7 \pm 1$ & $6 \pm 2$ \\
& 1000 & $89.2 \pm 0.8$ & $94.8 \pm 2.5$ & $51 \pm 2$ & $91 \pm 27$ \\
$1,25-(\mathrm{OH})_{2} \mathrm{D}_{3}$ & 10 & $54.3 \pm 3.3$ & $64.5 \pm 5.8$ & $38 \pm 13$ & $94 \pm 23$ \\
& 0.1 & $\mathrm{~ns}$ & $\mathrm{~ns}$ & $22 \pm 5$ & $48 \pm 0.1$ \\
& 1000 & $87.7 \pm 3.6$ & $93.2 \pm 1.3$ & $54 \pm 22$ & $68 \pm 26$ \\
Analog 1 & 10 & $49.3 \pm 13.2$ & $50.8 \pm 5.5$ & $39 \pm 18$ & $108 \pm 32$ \\
& 0.1 & $\mathrm{~ns}$ & $\mathrm{~ns}$ & $10 \pm 3$ & $14 \pm 2$ \\
Analog 2 & 1000 & $73.8 \pm 3.8$ & $86.3 \pm 5.2$ & $59 \pm 16$ & $104 \pm 17$ \\
& 10 & $67.8 \pm 7.9$ & $77.6 \pm 6.9$ & $55 \pm 10$ & $112 \pm 18$ \\
& 0.1 & $46.5 \pm 12.4$ & $59.4 \pm 14.3$ & $46 \pm 8$ & $117 \pm 34$ \\
\hline
\end{tabular}

${ }^{1} \mathrm{NBT}$, nitro blue tetrazolium; ns, not screened

criptionaly via activation of $\mathrm{nVDR}$. Erks are not only activated in response to 1,25-dihydroxyvitamin $\mathrm{D}_{3}$, but also are translocated to the cell nucleus (Fig. 2). Also analog 2 with strong differentiation-inducing properties (Table 1) is able to induce rapid activation of Erks in HL-60 cells (Marcinkowska \& Kutner, 2002).

An elegant evidence that a mechanism unrelated to $\mathrm{nVDR}$ is involved in cell differentiation induced by an analog of vitamin $\mathrm{D}$ was published recently (Ji et al., 2002). The analog of vitamin $\mathrm{D}$ described there is 40 times less calcemic than 1,25-dihydroxyvitamin $\mathrm{D}_{3}$, but retains similar cell differentiation-inducing activity. It was shown that this analog up-regulates nVDR expression less than 1,25-dihydroxyvitamin $\mathrm{D}_{3}$. When an oligonucleotide containing the binding sequence for $\mathrm{nVDR}$ was added to the cells, the differentiation response to the analog was less inhibited than the differentiation in response to 1,25-dihydroxyvitamin $\mathrm{D}_{3}$.

\section{MEMBRANE VITAMIN D RECEPTOR PROTEIN}

The contribution of a specific membrane receptor to the generation of rapid cellular responses to vitamin D was postulated already in the past (Nemere \& Szego, 1981a; 1981b; Lieberherr et al., 1989). A candidate for such a membrane receptor, a $65-\mathrm{kDa}$ protein, was purified from basal-lateral membranes of chick epithelial cells by ion-exchange chromatography (Nemere et al., 1994), but cDNA for this protein has not been cloned so far. However, biochemical data and immunochemical data obtained using a specific antibody (Ab99) revealed that this protein is not related to nVDR. This protein has been found not only in the membranes of cells from chick intestine, but also in cells from chick kidney and brain (Jia \& Nemere, 1999; Nemere et al., 2000; Nemere \& Campbell, 2000). And the most important: a protein recognized by the same Ab99 antibody was found in rat 

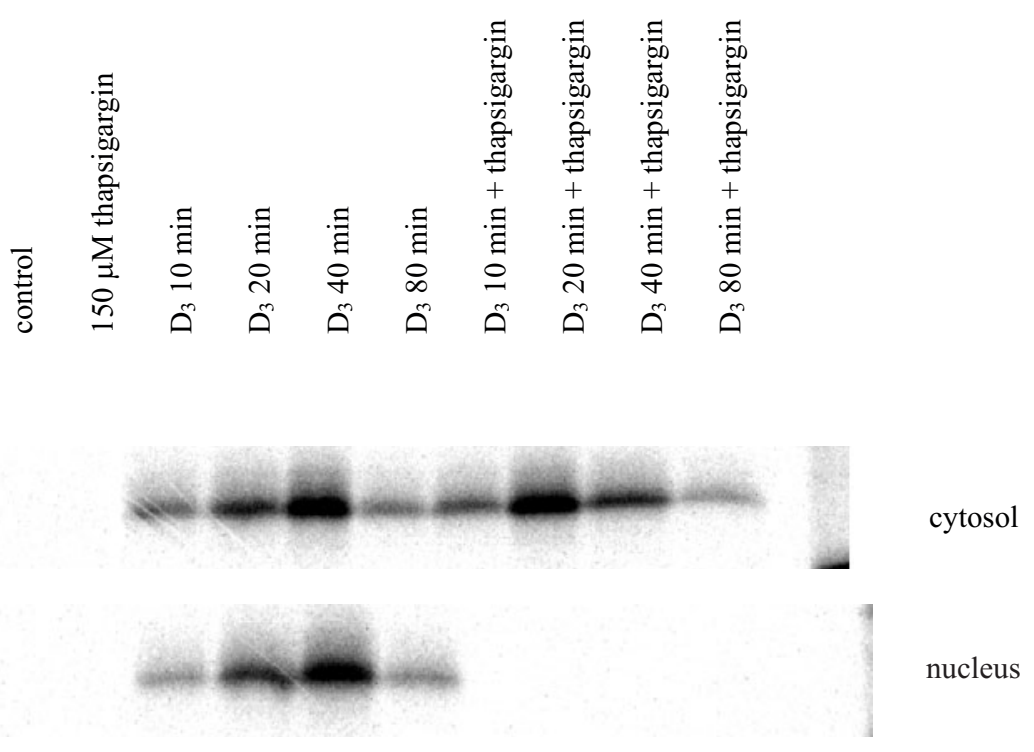

Figure 2. Activation and nuclear translocation of extracellular signal-regulated kinases (Erks) in HL-60 cells in response to 1,25 -dihydroxyvitamin $D_{3}$.

The figure is prepared according to Marcinkowska et al. (1997). Serum-starved HL-60 cells were treated with $1 \mu \mathrm{M}$ 1,25-dihydroxyvitamin $\mathrm{D}_{3}$ for indicated times. Then the cells were lysed and Erks were immunoprecipitated separately from the cytosolic and nuclear fractions. Activation of Erks was assayed by incorporation of $\gamma_{-}^{32} \mathrm{P}$ into myelin basic protein. Autoradiogram obtained in a representative experiment is presented. Thapsigargin (150 $\mu \mathrm{M})$, which in an indirect manner blocks translocation of proteins to the cell nucleus, was used as a control of appropriate separation of cellular fractions (Greber \& Gerace, 1995; Sweitzer \& Hanover, 1996).

chondrocytes. The rapid responses to 1,25 -dihydroxyvitamin $\mathrm{D}_{3}$ in these cells could be blocked by the antibody (Nemere et al., 1998; Pedrozo et al., 1999; Schwartz et al., 2002).

Another candidate for the membrane vitamin D receptor is annexin II (Baran et al., 2000). In rat osteoblastlike cells (ROS 24/1) $\left[{ }^{14} \mathrm{C}\right] 1,25$-dihydroxyvitamin $\mathrm{D}_{3}$ bromoacetate binds specifically to annexin II, and antiannexin II antibodies inhibit vitamin D-induced increase in intracellular calcium. It is not clear if in other cell types annexin II serves as a membrane vitamin $\mathrm{D}$ receptor. For example in rat matrix vesicles derived from rat chondrocytes it does not, since anti-annexin II antibodies do not inhibit the rapid responses generated by 1,25-dihydroxyvitamin $\mathrm{D}_{3}$ (Schwartz et al., 2002).

\section{RECEPTORS FOR PLANT STEROID HORMONES}

Brassinosteroids (BRs) are critical for the regulation of plant growth and development (Clouse \& Sasse, 1998). In order to find a receptor or other crucial components of BR signal transduction pathways mutants of $A$. thaliana insensitive to BRs and incapable of being rescued by exogenous BR application were screened (Clouse et al., 1996). Mutations were located in the brassinosteroid-insensitive 1 (BRI1) gene which encodes a transmembrane receptor kinase (Li \& Chory, 1997). The receptor consists of an extracellular domain with 25 tandem leucine-rich repeats that resemble the repeats found in animal hormone receptors, a transmembrane 70 amino-acid domain 
and a cytoplasmic kinase domain with serine/threonine specificity (Friedrichsen et al., 2000; Oh et al., 2000). It has been shown that BRs are direct ligands of BRI1 receptors (Wang et al., 2001). Upon activation by the ligand BRI1 receptor becomes autophosphorylated (Oh et al., 2000). Downstream signalling events have not been recognized as yet, however, negative-feedback regulation by a kinase-associated protein phosphatase has been suggested (Rodriguez, 1998). It seems that BR signalling through membrane receptors is widespread in the plant kingdom, since a rice homolog of BRI1 was found to mediate BR sensitivity as well (Yamamuro et al., 2000).

\section{POSSIBLE BIOLOGICAL FUNCTION OF MEMBRANE STEROID RECEPTORS}

It is believed that steroid hormones enter animal cells due to their lipophilic nature by simple diffusion, and that this entry is regulated by extracellular concentration resulting from the balance between synthesis and degradation of the hormone. However, the possibility that cellular entry of steroid hormones is mediated by appropriate membrane receptors should be taken into consideration (Nemere \& Szego, 1981a). Actually some data supporting this hypothesis have been provided (Nemere et al., 2000). Intestinal epithelial cells untreated and treated with 1,25-dihydroxyvitamin $\mathrm{D}_{3}$ were stained with an anti-membrane VDR antibody (Ab99) and investigated by electron microscopy. The experiments revealed that in the hormone-treated cells the protein recognized by this antibody is translocated to the cell nucleus after $10 \mathrm{~s}$. The presence of cell-surface receptors, as it appears to be in the case of 1,25-dihydroxyvitamin $\mathrm{D}_{3}$, may represent a new mechanism for membrane crossing. Active transport or at least facilitated diffusion of the hormone through the membrane might be an advan- tage, particularly at a lower extracellular level of the vitamin. Additionally, receptor-mediated transport of steroids into cells might be advantageous for the regulation by the cellular homeostasis-maintaining system compared to free diffusion.

It must be mentioned here that at least some polypeptide growth factors, in addition to their classic cell-membrane-mediated activity, like steroid hormones, exhibit also an intracellular mode of action similar to that of steroid hormones (Mason, 1994). The high molecular mass isoforms of FGF-2 and nuclear FGF-3 are the best described examples of endogenous nuclear growth factors. Furthermore there is an increasing body of evidence that some of the polypeptides are able to enter cells as exogenous proteins (Więdłocha, 1999; Clague \& Urbe, 2001). Although the mechanism of cell entry is poorly understood, the intracellular location of exogenous growth factors indicates that they can act in different cellular compartments and likely exhibit distinct actions.

It has been shown that FGF-1 binding to a high affinity tyrosine kinase receptor is necessary for cell entry (Klingenberg et al., 1998). After receptor binding followed by endocytosis, the growth factor is able to traverse cellular membranes in order to reach the cytosol and the nuclear compartment. Inside the cells FGF-1 binds to a $42 \mathrm{kDa}$ protein named FIBP (FGF-1 binding protein) which localizes mainly in the cell nucleus and partly in the cytosol (Kolpakowa et al., 1998). It does not quite fit into the paradigm that protein growth factors act only through surface receptors inducing signaling by phosphorylation of intracellular second messengers. However, this dual mechanism of FGF-1 signaling seems to be required to induce cell proliferation at least in some types of cells (Więdłocha et al., 1996; Klingenberg et al., 1998).

Vitamin $\mathrm{D}_{3}$ as well as other steroid hormones also exhibit a dual mode of action. Intracellularly, by direct binding to nVDR and by a putative (not yet cloned) specific cell-sur- 
face receptor regulating a novel-signaling pathway. It is interesting that although steroid hormones and growth factors represent chemically and structurally different agents, they are able to activate similar second messengers like PKC, PKA, PLC, MAP kinases or increase the intracellular level of $\mathrm{Ca}^{2+}$ in a rapid, transcription-independent manner regulated by membrane associated receptors. This phenomenon indicates that certain part of the signaling mechanism is common for many different regulatory agents.

We would like to thank Dr. Pierre Weber from Hoffmann-la Roche S.A., Pharma Preclinical Research in Basel (Switzerland) for providing us with 1,25-dihydroxyvitamin $\mathrm{D}_{3}$ and Prof. Andrzej Kutner from the Pharmaceutical Research Institute in Warsaw (Poland) for the vitamin D analogs.

\section{R E F E R E N C E S}

Baran DT, Quail JM, Ray R, Leszyk J, Honeyman T. (2000) Annexin II is the membrane receptor that mediates the rapid actions of $1 \alpha, 25$-dihydroxyvitamin $\mathrm{D}_{3}$. J Cell Biochem.; 78: 34-46.

Bollenbacher WE, Vedeckis WV, Gilbert LI. (1975) Ecdysone titres and prothoracic gland activity during the larval-pupal development of Manduca Sexta. Dev Biol.; 44: 46-53.

Bouillon R, Okamura WH, Norman AW. (1995) Structure-function relationships in the vitamin D endocrine system. Endocrinol Rev.; 16: $200-57$.

Castoria G, Barone MV, Di Domenico M, Bilancio A, Ametrano D, Migliaccio A, Auricchio F. (1999) Non-transcriptional action of oestradiol and progestin triggers DNA synthesis. EMBO J.; 18: 2500-10.

Castoria G, Migliaccio A, Bilancio A, Di Domenico M, de Falco A, Lombardi M, Fiorentino R, Varricchio L, Barone MV, Auricchio F. (2001) PI3-kinase in concert with Src promotes the S-phase entry of oestradiol-stimulated MCF-7 cells. EMBO J.; 21: 6050-9.

Chodyński M, Wojciechowska W, Halkes SJ, van de Velde J-P, Kutner A. (1997) Synthesis and in vitro evaluation of side-chain unsaturated analogs of 24a,24b-dihomo-1,25-dihydroxycholecalciferol. Steroids.; 62: 546-53.

Chodyński M, Wietrzyk J, Marcinkowska E, Opolski A, Szelejewski W, Kutner A. (2002) Synthesis and antiproliferative activity of side-chain unsaturated and homologated analogs of 1,25-dihydroxyvitamin $\mathrm{D}_{2}$. (24E)-(1S)-24-Dehydro-24a-homo-1,25-dihydroxyergocalciferol and congeners. Steroids.; 67: 789-98.

Clague MJ, Urbe S. (2001) The interface of receptor trafficking and signalling. J Cell Sci.; 114: $3075-81$.

Clouse SD, Sasse J. (1998) Brassinosteroids: essential regulators of plant growth and development. Annu Rev Plant Physiol Plant Mol Biol.; 49: 427-51.

Clouse SD, Langford M, McMorris TC. (1996) A brassinosteroid-insensitive mutant in Arabidopsis thaliana exhibits multiple defects in growth and development. Plant Physiol.; 111: $671-8$.

Di Croce L, Okret S, Kersten S, Gustafsson J-A, Parker M, Wahli W, Beato M. (1999) EMBO workshop report: steroid and nuclear receptors. EMBO J.; 18: 6201-10.

Evans RM. (1988) The steroid and thyroid hormone receptor superfamily. Science.; 240 : 889-95.

Friedrichsen DM, Joazeiro CA, Li J, Hunter T, Chory J. (2000) Brassinosteroid-insensitive-1 is a ubiquitously expressed leucine-rich repeat receptor serine/threonine kinase. Plant Physiol.; 123: 1247-56.

Greber UF, Gerace L. (1995) Depletion of calcium from the lumen of endoplasmic reticulum reversibly inhibits passive diffusion and signal-mediated transport into the nucleus. $J$ Cell Biol.; 128: 5-14.

Ji Y, Wang X, Donnelly RJ, Uskokovic MR, Studzinski GP. (2002) Signalling of monocytic differentiation by a non-hyper- 
calcemic analog of vitamin $\mathrm{D}_{3}, 1,25(\mathrm{OH})_{2} 5,6$ trans-16-ene-vitamin $\mathrm{D}_{3}$, involves nuclear vitamin $\mathrm{D}$ receptor (nVDR) and non-nVDR-mediated pathways. J Cell Physiol.; 191: $198-207$.

Jia Z, Nemere I. (1999) Immunochemical studies on the putative plasmalemmal receptor for 1,25-dihydroxyvitamin $\mathrm{D}_{3}$. II. Chick kidney and brain. Steroids.; 64: 541-50.

Jones G, Strugnell SA, DeLuca HF. (1998) Current understanding of the molecular actions of vitamin D. Physiol Rev.; 78: 1193-231.

Kelly MJ, Lagrange AH, Wagner EJ, Rønnekleiv OK. (1999) Rapid effects of estrogen to modulate $\mathrm{G}$ protein-coupled receptors via activation of protein kinase A and protein kinase $\mathrm{C}$ pathways. Steroids.; 64: 64-75.

Klingenberg O, Więdłocha A, Rapak A, Munoz R, Falnes PO, Olsnes S. (1998) Inability of the acidic fibroblast growth factor mutant K132E to stimulate DNA synthesis after translocation into cells. $J$ Biol Chem.; 273: 11164-72.

Kolpakowa E, Więdłocha A, Stenmark H, Klingenberg O, Falnes P, Olsnes S. (1998) Cloning of an intracellular protein that binds selectively to mitogenic acidic fibroblast growth factor. Biochem J.; 336: 213-22.

Li J, Chory JA. (1997) Putative leucine-rich repeat receptor kinase involved in brassinosteroid signal transduction. Cell.; 90: 929-38.

Lieberherr M, Grosse B, Duchambon P, Drueke T. (1989) A functional cell surface type receptor is required for the early action of 1,25-dihydroxyvitamin $\mathrm{D}_{3}$ on the phosphoinositide metabolism in rat enterocytes. J Biol Chem.; 264: 20403-6.

Machelon V, Nome F, Tesarik J. (1998) Nongenomic effects of androstenedione on human granulosa luteinizing cells. J Clin Endocrinol Metab.; 83: 263-9.

Marcinkowska E. (1998) Ph.D. Thesis. Institute of Immunology and Experimental Therapy, Polish Academy of Sciences, Wrocław, Poland (in Polish).
Marcinkowska E, Kutner A. (2002) Side-chain modified vitamin $\mathrm{D}$ analogs require activation of both PI 3-K and erk1,2 signal transduction pathways for differentiation of human promyelocytic leukemia cells. Acta Biochim Polon.; 49: 393-406.

Marcinkowska E, Więdłocha A, Radzikowski C. (1997) 1,25-Dihydroxyvitamin $\mathrm{D}_{3}$ induced activation and subsequent nuclear translocation of MAPK is upstream regulated by PKC in HL-60 cells. Biochem Biophys Res Commun.; 241: 419-26.

Marcinkowska E, Kutner A, Radzikowski C. (1998) Cell differentiating and anti-proliferative activity of side-chain modified analogues of 1,25-dihydroxyvitamin $\mathrm{D}_{3} . J$ Steroid Biochem Mol Biol., 67: 71-8.

Mason IJ. (1994) The ins and outs of fibroblast growth factors. Cell.; 78: 547-52.

Migliaccio A, Pagano M, Auricchio F. (1993) Immediate and transient stimulation of protein tyrosine phosphorylation by estradiol in MCF-7. Oncogene.; 8: 2183-91.

Migliaccio A, Di Domenico M, Castoria G, de Falco A, Bontemp P, Nola E, Auricchio F. (1996) Tyrosine kinase/p21ras/MAP-kinase pathway activation by estradiol-receptor complex in MCF-7 cells. EMBO J.; 15: 1292-300.

Migliaccio A, Piccolo D, Castoria G, Di Domenico M, Bilancio A, Lombardi M, Gong W, Beato M, Aurrichio F. (1998) Activation of the Src/p21ras/Erk pathway by progesterone receptor via cross-talk with estrogen receptor. EMBO J.; 17: 2008-18.

Nemere I, Szego C. (1981a) Early actions of parathyroid hormone and 1,25-dihydroxycholecalciferol on isolated epithelial cells from rat intestine: I. Limited lysosomal enzyme release and calcium uptake. Endocrinology.; 108: 1450-62.

Nemere I, Szego C. (1981b) Early actions of parathyroid hormone and 1,25-dihydroxycholecalciferol on isolated epithelial cells from rat intestine: II. Analyses of additivity, contribution of calcium, and modulatory influence of indomethacin. Endocrinology.; 109: 2180-87. 
Nemere I, Dormanen MC, Hammond MW, Okamura WH, Norman AW. (1994) Identification of a specific binding protein for $1 \alpha, 25$-dihydroxyvitamin $\mathrm{D}_{3}$ in basal-lateral membranes of chick intestinal epithelium and relationship to transcaltachia. $J$ Biol Chem.; 269: 23750-6.

Nemere I, Campbell K. (2000) Immunochemical studies on the putative plasmalemmal receptor for 1,25-dihydroxyvitamin $\mathrm{D}_{3}$. III. Vitamin D status. Steroids.; 65: 451-7.

Nemere I, Schwartz Z, Pedrozo H, Sylvia VL, Dean DD, Boyan BD. (1998) Identification of a membrane receptor for 1,25-dihydroxyvitamin $\mathrm{D}_{3}$ which mediates rapid activation of protein kinase C. J Bone Miner Res.; 13: 1353-9.

Nemere I, Ray R, McManus W. (2000) Immunochemical studies on the putative plasmalemmal receptor for $1,25(\mathrm{OH})_{2} \mathrm{D}_{3}$. I. Chick intestine. Am J Physiol Endocrinol Metab.; 278: E1104-14.

Oh M-H, Ray WK, Huber SC, Asara JM, Gage DA, Clouse SD. (2000) Recombinant brassinosteroid insensitive 1 receptor-like kinase autophosphorylates on serine and threonine residues and phosphorylates a conserved peptide motif in vitro. Plant Physiol.; 124: $751-65$.

Pedrozo HA, Schwartz Z, Rimes S, Sylvia VL, Nemere I, Posner GH, Dean DD, Boyan BD. (1999) Physiological importance of the $1,25(\mathrm{OH})_{2} \mathrm{D}_{3}$ membrane receptor and evidence for a membrane receptor specific for $24,25(\mathrm{OH})_{2} \mathrm{D}_{3}$. J. Bone Miner Res.; 14: 856-67.

Pietras RJ, Szego CM. (1977) Specific binding sites for oestrogen at the outer surface of isolated endometrial cells. Nature.; 265: 69-72.

Razandi M, Pedram A, Greene GL, Levin ER. (1999) Cell membrane and nuclear estrogen receptors (ERs) originate from a single transcript: studies of ERalpha and ERbeta expressed in Chinese hamster ovary cells. Mol Endocrinol.; 13: 307-19.

Razandi M, Oh P, Pedram A, Schnitzer J, Levin ER. (2002) ERs associate with and regulate the production of calveolin: implications for signalling and cellular actions. $\mathrm{Mol}$

Endocrinol.; 16: 100-15.

Rochel N, Wurtz JM, Mitschler A, Klaholz B, Moras D. (2000) The crystal structure of the nuclear receptor for vitamin $\mathrm{D}$ bound to its natural ligand. Mol Cell.; 5: 173-9.

Rodriguez PL. (1998) Protein phosphatase 2C (PP2C) function in higher plants. Plant Mol Biol.; 38: 919-27.

Rosner W, Hryb J, Khan MS, Nakhla AM, Romas NA. (1999) Androgen and estrogen signalling at the cell membrane via G-proteins and cyclic adenosine monophosphate. Steroids.; 64: 100-6.

Schwartz Z, Schlader DL, Swain LD, Boyan BD. (1988) Direct effects of 1,25-dihydroxyvitamin $\mathrm{D}_{3}$ and 24,25-dihydroxyvitamin $\mathrm{D}_{3}$ on growth zone and resting zone chondrocyte membrane alkaline phosphatase and phospholipase-A ${ }_{2}$ specific activities. Endocrinology.; 123: 2878-84.

Schwartz Z, Sylvia VL, Larsson D, Nemere I, Casasola D, Dean DD, Boyan BD. (2002) $1 \alpha, 25(\mathrm{OH})_{2} \mathrm{D}_{3}$ regulates chondrocyte matrix vesicle protein kinase $\mathrm{C}(\mathrm{PKC})$ directly via G-protein-dependent mechanisms and indirectly via incorporation of PKC during matrix vesicle biogenesis. $J$ Biol Chem.; 277: 11828-37.

Selye H. (1941) Anesthetic effect of steroid hormones. Proc Soc Exp Biol Med.; 46: 116-21.

Sweitzer TD, Hanover JA. (1996) Calmodulin activates nuclear protein import: a link between signal transduction and nuclear transport. Proc Natl Acad Sci U S A.; 93: 14574-9.

Tocchini-Valentini G, Rochel N, Wurtz JM, Mitschler A, Moras D. (2001) Crystal structures of the vitamin $\mathrm{D}$ receptor complexed to superagonist 20-epi ligands. Proc Natl Acad Sci U S A.; 98: 5491-6.

Wang Z-Y, Chory J. (2000) In Recent advances in phytochemistry. Vol. 34, Evolution of methabolic pathways. Romeo JM, Ibrahim R, Varin L, DeLuca V. eds, pp. 409-31. Elsevier Science, Oxford. 
Wang Z-Y, Seto H, Fujioka S, Yoshida S, Chory J. (2001) BRI1 is a critical component of a plasma-membrane receptor for plant steroids. Nature.; 410: 380-3.

Więdłocha A. (1999) Following angiogenin during angiogenesis: a journey from the cell surface to the nucleolus. Arch Immunol Ther Exp.; 47: 299-305.

Więdłocha A, Falnes PO, Rapak A, Munoz R, Klingenberg O, Olsnes S. (1996) Stimulation of proliferation of a human osteosarcoma cell line by exogenous acidic fibroblast growth factor requires both activation of receptor tyrosine kinase and growth factor internalization. Mol Cell Biol.; 16: 270-80.

Yamamuro C, Ihara Y, Wu X, Noguchi T, Fujioka S, Takatsuto S, Ashikari M, Kitano H, Matsuoka M. (2000) Loss of function of a rice brassinosteroid insensitive 1 homolog prevents internode elongation and bending of the lamina joint. Plant Cell.; 12: 1591-606. 